\title{
Indonesia Environmental Diplomacy Reformed: Case Studies of Greening ASEAN Way and Peat Restoration Agency
}

\author{
Verdinand Robertua ${ }^{1}$, Lubendik Sigalingging ${ }^{2}$ \\ ${ }^{1}$ International Relations, Universitas Kristen Indonesia,Jakarta, Indonesia \\ ${ }^{2}$ Peat Restoration Agency, Republic of Indonesia
}

\section{ARTICLE INFORMATION}

\section{SUBMISSION TRACK}

Recieved : :19, January, 2019

Final Revision : : 16, May, 2019

Available Online: 30, May, 2019

\section{KEYWORD}

Indonesia environmental diplomacy, greening ASEAN Way, peat restoration agency, English School

\begin{abstract}
There is an increasing pessimism on the role of state as the guardian of environmental livelihood due to the recurring of environmental disasters. Moving to a new global environmental governance seems inevitable due to the importance of economic development and social justice within the classical definition of environmental diplomacy. By using the case of "greening ASEAN Way" and the establishment of Indonesia's peat restoration agency, this article attempted to reinvigorate environmental diplomacy using English School theoretical framework. This research obtained primary data from semi-structured interview with Indonesian officials in Ministry of Foreign Affairs and Peat Restoration Agency as well as from the observation of the implementation of peatland restoration in Indonesia. This research has three conclusions. Firstly, Indonesia is an important actor in the mitigation of many regional and global environmental issues including forest fires and transboundary haze. Secondly, the ratification of ASEAN Agreement on Transboundary Haze Pollution and the establishment of peat restoration agency are part of the reinvigoration of Indonesia environmental diplomacy. Lastly, Indonesia's reformed environmental diplomacy still faced problem on the relationship between central government and local government.
\end{abstract}

\section{KATA KUNCI \\ Diplomasi lingkungan Indonesia, greening \\ ASEAN Way, Badan Restorasi Gambut,}

English School

CORRESPONDENCE

E-mail: verdinand.robertua@uki.ac.id

\begin{abstract}
ABSTRAK
Banyaknya bencana lingkungan yang terjadi menipiskan harapan terhadap peran negara sebagai pelindung lingkungan hidup. Tata kelola lingkungan global yang baru seperti tidak terelakkan seiring dengan signifikansi pertumbuhan ekonomi dan keadilan sosial dalam definisi klasik diplomasi lingkungan. Dengan menggunakan studi kasus "greening ASEAN Way" dan pembentukan Badan Restorasi Gambut, artikel ini berusaha melakukan reformulasi terhadap konsep diplomasi lingkungan dengan menggunakan kerangka teori English School. Data primer penelitian ini diperoleh dengan wawancara semi-terstruktur dengan pengambil kebijakan di Kementerian Luar Negeri dan Badan Restorasi Gambut serta observasi di wilayah
\end{abstract}


restorasi gambut di Indonesia. Penelitian ini memiliki tiga kesimpulan. Pertama, Indonesia merupakan aktor penting dalam mitigasi isu-isu lingkungan dalam level regional and global termasuk kebakaran hutan dan pencemaran udara lintas batas. Kedua, ratifikasi ASEAN Agreement on Transboundary Haze Pollution dan pembentukan Badan Restorasi Gambut merupakan bagian dari penyegaran kembali diplomasi lingkungan Indonesia. Terakhir, diplomasi lingkungan Indonesia masih menghadapi masalah terkait relasi antara pemerintah pusat dan pemerintahan lokal.

\section{Introduction}

Indonesian environmental diplomacy is complex and dynamic. As the second largest tropical forest and the largest peat forest in the world, Indonesia is in the crossroad formulating its environmental diplomacy. Forest fires, transboundary haze and biodiversity loss have put Indonesian environmental diplomacy in limbo. This research highlighted two primary problems in Indonesian environmental diplomacy namely the lack of coordination among states and the marginalization of local wisdom. Using the case studies of greening ASEAN Way and Peat Restoration Agency, this research aimed to trace and capture the dynamic of Indonesian environmental diplomacy.

In the beginning of this article, the authors will expose the conceptual framework of environmental diplomacy in English School theoretical point of view. There is an urgent need for transforming environmental diplomacy from state-centric activities into a new hybrid global environmental governance due to recurrence of global environmental crisis. This hypothesis will be evaluated based on two cases. Firstly, Indonesia ratification of ASEAN Agreement on Transboundary Haze Pollution is a form of Indonesian environmental diplomacy in facing forest fires and transboundary haze. Secondly, the conflict between global environmental value and local wisdom can be seen in the implementation of Peat Restoration Agency. Critical analysis on these two cases showed us a new complexity on Indonesian environmental diplomacy.

Environmental issues are emerged as serious challenge to the legitimacy of states in International Relations. According to Hurrell ${ }^{1}$, states are still considered as the primary actor in implementing policy and allocating resources in the context of mitigation of global and national environmental problems. However, this domination is being constantly challenged by the presence of multinational corporations (MNCs) and civil society. MNCs have voiced their protest regarding the impact of climate change and implemented many initiatives to complement global arrangement. It became even more crucial when civil society used their normative power to march against government and created self-sustained global environmental movement. $^{2}$

Environmental diplomacy is an effort to integrate environmental issues into foreign policy of a nation. In the midst of thousands

\footnotetext{
${ }^{1}$ Falkner, Robert. 2009. Business Power and Conflict in International Environmental Politics. New York: Palgrave Macmillan.

2 Ardhian, David, Soeryo Adiwibowo, and Ekawati Sri Wahyuni. 2016. "Peran dan Strategi Organisasi Non Pemerintah dalam Arena Politik Lingkungan Hidup." Sodality 210-216.
} 
of bilateral and multilateral negotiations among nations, environmental diplomacy is a tool for governments to achieve a new form of cooperation in addressing urgent environmental problems. The nature of environmental problems is global in scope, transboundary and stateless. The most effective solution to environmental problems requires complex interdependence among nations and non-state actors. ${ }^{3}$

Benedick $^{4}$ argued that one of the stumbling block of environmental diplomacy is the equity issue between developed and developing countries. For poor countries, the difference in wealth and resource possession should be primary indicator for determining the degree of environmental responsibility. Rich countries have to allocate bigger resources to change their consumption and production behaviour meanwhile poor countries have to focus to eradicate poverty and raise standard of living. The denial of different degree of environmental responsibility is a factor of lack of coordination and compliance toward multilateral environmental agreement including the Paris Agreement.

The problem of environmental diplomacy is not only about equity issue but also the hierarchy of values and principles. The adoption of environmental protection in foreign policy brings a new complexity of values and principles. Narain ${ }^{5}$ asked whether "environmental diplomacy has turned into petty business transactions, not the establishment of fair and global

3 Benedick, Richard E. 1999. "Diplomacy for the Environment." In Environmental Diplomacy, by American Institute for Contemporary German Studies, 3-13. Washington: American Institute for Contemporary German Studies.

${ }^{4}$ Ibid

${ }^{5}$ Narain, Sunita. 1999. "Environmental Diplomacy in an Unequal World." In Environmental Diplomacy, by American Institute for Contemporary German Studies, 17-25. Washington: American Institute for Contemporary German Studies. environmental governance systems". Environmental diplomacy focused too much on making environmental protection profitable neglecting the principle of justice, fairness, and equality. The interaction between developed and developing countries is an exclusive domain of environmental diplomacy ignoring values and principles motivating interaction among members within a local organization. Therefore, the interaction between international agenda and domestic setting is an imperative. ${ }^{6}$

The failure of environmental diplomacy in capturing principles and mediating the conflict can be understood using Ali and Vladich's concept of environmental diplomacy. According to them, environmental diplomacy consists of three interlinked components; economic growth, environmental protection and social justice. $^{7}$

Narain's question on values in environmental diplomacy is related with the conflict between environmental protection and social justice. There is an identity crisis of environmental diplomacy questioning the "real motivation" behind environmental protection platform. Meanwhile Benedick's argument on the difference of environmental responsibility deals with the competition between economic growth and environmental protection. Environmental diplomacy contained a dilemma: "how to achieve economic growth without sacrificing environmental protection?" Without answering these question, environmental diplomacy is merely a form of environmental cooperation between states.

Quayle, Linda. 2013. "National and Regional Obligations, the Metaphor of Two-Level Games, and the ASEAN Socio-Cultural Community." Asian Politics \& Policy 5 (4): 499-521.

Ali, Saleem, and Helena Vladich. 2016. "Environmental Diplomacy." In The SAGE Handbook of Diplomacy, by Costas Constantinou, Pauline Kerr and Paul Sharp, 601-616. London: SAGE. 
The emergence of multi-stakeholder initiatives (MSIs) is a sign of protest toward the state-centric environmental diplomacy. Governments are not responsible for protecting environment and they are ineffective in working together fighting against environmental problem. ${ }^{8}$ The presence of civil society in global environmental politics is an indication of the failure of government multilateralism. Global environmental governance become the arena for civil society to be stronger against the states. There are many derivative concepts from global environmental governance such as multi-stakeholder initiative and public-private partnership.

Another example of the crisis of environmental diplomacy is Paris Agreement. Paris Agreement has been criticized as weak agreement as the United States are not interested in developing them. They are mainly marginalized as environmental issues is sidelined in the global politics overshadowed by security crisis is North Korea, South China Sea and Middle East. However, Stockholm Conference 1972 and Rio Conference 1992 were the historical moment showing global solidarity overcome egoistic self-interest of nations. ${ }^{9}$ Water crisis, famine, forest fires, transboundary haze pollution, animal extinction and climate change are pushing leaders to reform their mindset regarding environmental issues.

Stockholm Conference and Rio Conference have successfully produced United Nations Environmental Program and Kyoto Protocol respectively. After then, COP 21 in Paris in 2015 produced Paris Agreement that set global warming below two degrees Celsius compared to pre-

8 Chasek, Pamela S. 2001. Earth Negotiations: Analyzing Thirty Years of Environmental Diplomacy. Tokyo: United Nations University Press.

${ }^{9}$ Bernstein, Steven. 2001. The Compromise of Liberal Environmentalism. New York: Columbia University Press. industrial levels. Paris Agreement entered into force after more than 55 countries have ratified it and on 22 April 2016, there were 174 countries ratified it. Paris Agreement is now a global binding international law. The Trump's decision to exit Paris Agreement has put environmental diplomacy in limbo. The US is the biggest carbon emitter in the world and the political superpower in global military and political arrangement. Without the US' engagement, the Paris Agreement is just another "ordinary" environmental law.

Above literature review indicated that there are constant growing dissatisfaction toward national leaders in using environmental diplomacy in building effective global platform in addressing transboundary environmental challenges. Skepticism toward state is inevitable. Even though there are hundreds of global and regional environmental agreements (MEAs), activists and ecologists perceived negatively toward the capacity and the implementation of MEAs. ${ }^{10}$ The debate regarding the legitimacy of states in global environmental politics can be analyzed using multiple International Relations theories including English School.

English School is popular as the theory of "debating the debate" due to the presence of its contradicting pillars namely pluralism and solidarism. Pluralism is a worldview championing diplomacy, international organization and international trade as essential component of international order. ${ }^{11}$ Sovereignty, non-violence and state are the key words of pluralism. Solidarism is simply an anti-thesis of pluralism. Many English School scholars attempted to understand the significance of this debate (Buzan 2004,

${ }^{10}$ French, Hillary. 1999. "How Can We Reconcile the Slow Pace of International Diplomacy with the Growing Urgency of Global Ecological Decline." In Environmental Diplomacy, by American Institute for Contemporary German Studies, 13-17. Washington: American Institute for Contemporary German Studies.

${ }^{11}$ Bull, Hedley. 1977. The Anarchical Society: A Study of Order in World Politics. Basingstoke: Palgrave. 
Falkner 2012, Cochran 2009, Jackson 2009). Instead of debating the debate of pluralism and solidarism, this article attempted to evaluate the domination/contraction of pluralism/solidarism in environmental politics. Is it true that the crisis of environmental diplomacy indicated the crisis of pluralism in Environmental Studies of English School?

\section{Research Method}

In addressing the conceptual problem of Indonesia environmental diplomacy, the authors asked head of Peat Restoration Agency, Republic of Indonesia, Nazir Foead and head of Greenpeace Indonesia, Leonard Simajuntak to express their views regarding the response of Indonesian government in environmental issues. Both speakers are selected due to their capacity and competence in environmental issues globally and nationally.

Their views will be analyzed using English School theory in order to find the new Indonesia environmental diplomacy. English School theory has pluralism and solidarism which both of them has competing views and perspective. Both views will be relevant in minimizing subjective interpretation of authors.

\section{Discussion and Analysis}

To answer the question, the author analyzed the case of haze conflict between Singapore, Malaysia and Indonesia. Since 1998, forest fires in Indonesia and transboundary haze pollution in Malaysia and Singapore are classified not only as regional environmental problems but also global environmental disaster. Forest fires in Sumatra and Kalimantan contributed to haze in Singapore and Malaysia due to their geographical proximity. There are many scientific reports explaining factors of forest fires starting from the vulnerability of peat fires to the impact of El-Nino. However, International Relations experts showed that forest fires were also related to the absence of environmental responsibility among leaders and corporation in exploiting forests. The negative impact of forest fires is obvious. Haze is not only harmed peoples' health but also harmed economic growth and political order. Tourists' number were declining and peoples protested massively to the governments contributing to the declining political support both in Indonesia, Singapore and Malaysia. Forest fires threatened biodiversity and animal habitat as well as the living space of indigenous peoples. Indonesia is home to Earth's most threatened tribes namely Orang Rimba, indigenous tribe in Sumatra. ${ }^{12}$ Orang Rimba's population decreased $30 \%$ per year and they are in the brink of extinction due to the expansion of palm oil plantation and forest fires.

Haze conflict is a test case for environmental diplomacy. As elaborated earlier, the skepticism toward environmental diplomacy is based on the failure of states in overcoming the degree of environmental responsibility. In the case of haze, Indonesian government didn't accept as the sole responsible party of forest fires and transboundary haze. Despite of having the second largest tropical forest in the Earth, Indonesia blamed Singaporean and Malaysian corporation as the perpetrators of forest fires. ${ }^{13}$ There are criminal suspects of forest fires from Malaysia- and Singaporebased palm oil corporation. Meanwhile, Indonesia defended its right to exploit forest

\footnotetext{
${ }^{12}$ The Guardian. 2016. Indonesia's forest fires threaten Sumatra's few remaining Orang Rimba. June 7. Accessed August 7, 2017. https://www.theguardian.com/globaldevelopment/2016/jun/07/indonesia-forest-firesthreaten-sumatras-few-remaining-orang-rimba.

3 Deutsche Welle. 2006. Asap dan Perang Kata-Kata. Desember 14. Accessed Desember 2, 2016. http://www.dw.com/id/asap-dan-perang-kata-kata/a16897824
} 
for eradicating poverty and raising standard of living. Wibisono argued that Indonesian people should not only become "security officer" of Indonesian forest. Rich countries are richer using Indonesian forest meanwhile Indonesian people are still poor acting only as the guardian of forest. ${ }^{14}$

In this way, environmental diplomacy is a tool to defend the Indonesian rights to exploit forest. To understand the crisis of environmental diplomacy, we can learn from Clapp and Dauvergne's typology of international political economy of environment. According to them, social green is the group that advised radical transformation of national foreign policy. Global environmental crisis is inevitable due to "social injustice at both global and local level" and the solution is "reject industrialism and capitalism and reverse economic globalization". ${ }^{15}$ Of course, the solution is unfeasible for Indonesia, Malaysia and Singapore. Industrialism and capitalism are twin engines of new emerging economies that alleviated welfare to millions of peoples.

For social greens, environmental diplomacy is a tool for defending reputation and prestige among nation-states. It is useless to discuss the effectiveness of mitigation and restoration policy both at global and local level because industrialism and capitalism are dominating national economic agenda and marginalizing ecological justice everywhere. Due to the domination of industrialism and capitalism in all countries, "naming-and-shaming" should not be a strategy of environmental diplomacy. For social greens, "naming-andshaming" can only be used by an environmental superpower. Environmental

${ }^{14}$ Wibisono, Christianto. 2015. "Kedaulatan Asap RI." Kompas, October 27: 7.

${ }^{15}$ Clapp, Jennifer, and Peter Dauvergne. 2005. Path to a Green World: the Political Economy of Global Environment. Masschusets: MIT Press. superpower refers to the states and nations that able to reverse the domination of industrialism and capitalism and promoting ecological justice effectively. In reality, it is not exist.

This effort of making environmental diplomacy as a tool to hide the truth fitted to English School's research agenda in environmental studies. Most of English School scholars focused to challenge the hegemony of pluralism or solidarism and trace the dynamics between pluralism and solidarism. There are also growing interest among English School scholars to construct a new typology such as Barry Buzan's world society and Schouenberg's Scandinavian international society. ${ }^{16}$ This research aimed to understand the dynamic of certain "established concepts" such as sustainable development or environmental diplomacy. Rather than taking a concept as taken-forgranted, English School scholars should challenge the consensus among scholars and reformulate it with a new understanding. ${ }^{17}$

ASEAN Way is a form of environmental diplomacy. ASEAN Way is "a code of conduct for inter-state behaviour as well as a decision-making process based on consultation and consensus". ${ }^{18}$ If there is a regional problem, ASEAN member states should take non-confrontational approach in solving the problem. According to the advocate of ASEAN Way, sovereignty is the sacred element of regional order explaining

${ }^{16}$ Buzan, Barry. 2004. From International to World Society: English School Theory and the Social Structure of Globalisation. Cambridge: Cambridge University Press;

Schouenborg, Laust. 2013. The Scandinavian International Society: Primary Institutions and Binding Forces 1815-2010. Oxon: Routledge.

17 Liste, Philip. 2017. "International Relations Norms Research and the Legacies of Critical Legal Theory." 11th Pan-European Conference on International Relations (EISA). Barcelona: European International Studies Association. 1-22.

18 Acharya, Amitav. 1997. "Ideas, Identity, and Institution Building: From the 'ASEAN Way' to the 'Asia-Pacific' Way." Pacific Review 319-346. 
the absence of war in Southeast Asia since its formation in 1967. In the context of environmental issues, the advocates of ASEAN Way believed that states have responsibility protecting their ecosystem and natural resources and ASEAN Way provided "comfortable zone" for leaders and bureaucrats to implement environmental development projects.

As a form of environmental diplomacy, ASEAN Way is evident in the formation of ASEAN Agreement on Transboundary Haze Pollution (AATHP). In response to the recurrence of forest fires and transboundary haze, Singapore and Malaysia initiated regional multilateral environmental agreements preventing and mitigating the impact of transboundary haze. AATHP faced negative criticism from Indonesia due to the nature of AATHP as a binding agreement. Indonesian parliament feared that AATHP will be used by Singapore and Malaysia to punish Indonesia for its failure in preventing forest fires and transboundary haze. After Indonesian diplomats convinced the parliament that AATHP is another form of environmental diplomacy using ASEAN Way, Indonesian government ratified it in 2014. It takes 12 years for Indonesian parliament to ratify AATHP.

Meanwhile, environmental scholars accused that AATHP is another failure of ASEAN taking out ASEAN Way in dealing with environmental problems. The absence of law enforcement and sanction in AATHP is the primary obstacle of implementing AATHP in the national regulation. Some scholars used the European Union as a case study showing the advantage of including law enforcement and sanction in environmental agreements.

This research argued that ASEAN Way is "greened". Instead of looking ASEAN Way as a problem, this research offered a new perspective that ASEAN Way has helped states and governments in mitigating the regional environmental problem. Greening ASEAN Way started from the argument that there are multiple ways to influence national environmental foreign policy. "Naming-and-shaming" strategy is not the only way to change state behaviour. Greening ASEAN Way marked a new importance of dialogue and consultation as well as cooperation between states and sub-state actors in promoting environmental values. ASEAN member states admitted the impact of industrialization and capitalism but environmental diplomacy should be a tool for states in focusing "unexplored area" that is possible for empowering state capacity in correcting environmental failures such as peatland conservation or sustainable forest management.

Indonesian ratification of AATHP is an indication of a shift of the meaning of environmental diplomacy from social greens to institutionalists. According to Clapp and Dauvergne (2005), institutionalists focused on cooperation to bridge the gap between welfare, policy entrepreneurship and technology improvement with environmental problems. Instead of rejecting industrialization and capitalism, institutionalists offer long-term solution using comprehensive global network with non-state actor. ${ }^{19}$ Without Indonesian ratification to AATHP, improvement and innovation in sub-state level and national level in addressing forest fires and transboundary haze didn't gain its political legitimacy. In this way, greening ASEAN Way is a momentum of transformation from "treadmill growth" to strong environmental domestic institution. Instead of "naming-andshaming" approach of environmental diplomacy, greening ASEAN Way advised closer examination of domestic environmental policies and strategies in delivering environmental restoration and mitigation.

\footnotetext{
${ }^{19}$ Clapp, Jennifer, and Peter Dauvergne, Op.Cit.
} 
Diplomacy Reformed : Case Studies of Greening ASEAN Way and Peat

Restoration Agency

During Susilo Bambang Yudhoyono's leadership, environmental diplomacy is one of Indonesia's top foreign policy agenda and greening ASEAN Way is a consequence of Indonesia's environmentally-sound domestic policies. The first intersection between domestic and international policies in Indonesian environmental diplomacy is the United Nations Framework Convention of Climate Change (UNFCCC) meeting in Bali in 2007. President Susilo Bambang Yudhoyono (SBY) used all his political power to ensure the success of the meeting including the bureaucrats in Ministry of Foreign Affairs and State Ministry of Environment. It is a top-down strategy. ${ }^{20}$ Due to SBY's entrepreneurship, Bali meeting successfully adopted of Reducing Emission from Deforestation and Degradation Plus (REDD+) in Bali Agenda. REDD+ is a major concern for developing countries to gain assistance and facilitation from developed countries in implementing sustainable forest management.

Ratification of AATHP is the second intersection of domestic and international policies in Indonesian environmental diplomacy. Knowing environmental diplomacy as a top foreign policy agenda, Minister of Foreign Affairs Marty Natalegawa ordered diplomats in Directorate of ASEAN Cooperation to help AATHP into parliament's top law-making agenda. Nguitragool explained that AATHP has lack of support from Indonesian epistemic community. ASEAN was largely invisible in the global environmental policies in comparison with the United Nations. ${ }^{21}$

\footnotetext{
${ }^{20}$ Taufik, Kinanti Kusumawardhani.

2016."Indonesia'sEnvironmental Diplomacy under Yudhoyono: A Critical-Institutionalist-

Constructivist Analysis." The Hague Journal of Diplomacy 1-26

${ }^{21}$ Nguitragool, Paruedee. 2011. "Negotiating the Haze Treaty Rationality and Institutions in the Negotiations
}

Special instruction from Minister Marty is crucial in ensuring a smooth ratification of AATHP. In SBY's leadership, greening ASEAN Way is a part of Indonesian environmental diplomacy as a consequence of Indonesia activism in global environmental politics.

After Joko Widodo come into power, peatland protection received substantial attention and institutionalization. President Widodo established Badan Restorasi Gambut (BRG) in the beginning of 2016 to restore Indonesian degraded peatland and protect remaining fertile peatland. BRG has a mandate to restore about two millions of degraded peatland in seven provinces (Riau, South Sumatera, Jambi, Central Kalimantan, West Kalimantan, South Kalimantan and Papua).

The establishment of BRG marked a new era of Indonesian environmental diplomacy. SBY focused to implement emission reduction target through the implementation of REDD+ with the assistance of executive agency of REDD+ (BP REDD+) and National Council of Climate Change. Instead of empowering these institutions, President Widodo dismissed them in January 2015 and simplifying large bureaucracy with the integration of Ministry of Forestry and State Ministry of Environment into Ministry of Environment and Forestry. In the beginning of Widodo's era, streamlined communication and coordination between overlapping ministries is the key strategy in achieving political targets and promises.

Great forest fires and transboundary haze in 2015 shocked the world. It is estimated that about 2,6 million hectares of forest and land was burned. President Widodo received legitimacy crisis due to the recurrence of 1997's forest fires and transboundary haze. Instead of using

for the ASEAN Agreement on Transboundary Haze Pollution (2002)." Asian Survey 51 (2): 356-378. 
REDD+ framework in dealing with the problem, President Widodo launched a set of governmental policies in preventing forest fires including the establishment of BRG through President Regulation No. 1 Year 2016 and Government Regulation (PP) number 57 year 2016 on Protection and Management of Peat Ecosystems include banning land clearing in peatland area. Widodo's focus to peatland restoration raised pessimism from international community due to the increasing cost of financial burden in implementing peatland restoration target.

There is a contradiction between national regulation and local regulation. West Kalimantan has vast area of peatland and the local regulation allowed farmers to use fires to clear the land. In Local Law number 6 year 1998, local farmers can fire the land for two hectares area per person.22 This rule is against the national regulation banning the fires as a way to clear the land. This problem highlighted the debate between social justice and environmental protection as discussed by Narain (1999). To ensure effective implementation of environmental diplomacy, government need to cooperate with private sectors and sub-national actors. In this regard, peatland is transformed into a business deal between government and local communities with the purpose of preventing environmental problems and turning natural resources into profit. This is similar to Clean Development Emission in Kyoto Protocol. $\mathrm{CDM}$ is a carbon trading mechanism that allowed developed countries to transfer their emission to developing countries with financial contributions as its compensation. As Narain said, environmental diplomacy is trapped into a petty business financial transaction.

\footnotetext{
${ }^{22}$ Pontianak Post. 2016. Revisi Perda Karhutla. 22. Accessed 92018. https://www.pontianakpost.co.id/revisi-perdakarhutla.
}

Many palm oil corporations have voiced their protest regarding Indonesia's new policy regarding the ban or moratorium on plantation in peatland area. Ministry of industry has sent a letter to President Jokowi regarding the negative impact of Presidential Decree 57 in 2016. ${ }^{23}$ Alisjahbana and Busch (2017) have highlighted on how there are many weaknesses in the institutionalization of BRG. According to Alisjahbana and Busch, BRG has insufficient human resources, inadequate funding and inconsistent peatland regulation. ${ }^{24}$ As a new organization, BRG need strong political mandate in order to deal with huge multinational corporation and local leaders.

This research argued that BRG's method need to be elaborated further especially the technique in community empowerment. BRG has $3 \mathrm{R}$ method that consists of rewetting of degraded peatland, revegetation, and revitalization of local livelihoods. Rewetting and revegetating stand for peatland restoration and revitalizing stands for community empowerment. As stated in the background of chapter one, there is huge expansion of palm oil plantation in response to the growing need of palm oil worldwide. As the incentives for palm oil plantation is bigger that local farming, local community was poised to clear the land and make a canal for drying the peatland. Instead of punish local community for degrading peatland, government need to empower local community in resisting the conversion of

${ }^{23}$ The Jakarta Globe. 2017. Regulatory Challenges in Peatland Management. September 13. Accessed November 16, 2017. http://insight.jakartaglobe.id/indonesias-regulatorychallenges-people-planet-profit-peatlandmanagement/.

${ }^{24}$ Alisjahbana, Armida S., and Jonah M. Busch. 2017. "Forestry, Forest Fires, and Climate Change in Indonesia." Bulletin of Indonesian Economic Studies 111-136. 
peatland into palm oil plantation. Government need to focus to empower local business that based on sustainable agriculture such as coffee, chocolate, pineapple, dragon fruit or sagu; based on water such as beje ikan (fisheries) and based on ecosystem service such as carbon trade, eco-tourism, etc. Financial and technical aid would be some solution to address this deficit.

The importance of local sustainable economy is very important to integrate social justice and environmental protection. Article 33 of Indonesian constitution number 3 stated: "Earth, water and natural resources should be governed by the state and used to the greatest benefit of the people". This article emphasized the focus toward the local communities around the forest and peatland. Ensuring the benefit of peatland toward the community is one of primary objectives of Indonesian government. In this case, the integration of land reform and peatland restorations is very useful in reconstructing Indonesian environmental diplomacy. Peatland restoration should not only address the biodiversity, ecosystem and livelihood but also the improvement of welfare and social benefit. Jokowi's land reform should be seen as an integral part of peatland restorations based on Indonesian constitution article 33. The improvement of land reform should hand in hand with peatland restoration in addressing global environmental problems.

The implementation of article 33 is reflected in the Supreme Court decision to abandon Minister Regulation number 17 year 2017. Minister of Environment and Forestry issued a minister regulation number 17 year 2017 stating that industrial forest and palm oil that used peatland must be stopped. This regulation provoked protest from corporations and labor unions fearing the bankruptcy of the corporations and the loss of jobs. $^{25}$ Peatland restoration and conservation should not be against the article 33 and minister regulation 17/2017 didn't bring any positive impact with peatland restoration and land reform.

In the context of environmental diplomacy, McLellan has compared two different regime in handling global environmental problems. According to McLellan, "Indonesia must build the domestic credentials necessary to be considered a respected and capable player before it can lead on climate change internationally". ${ }^{26}$ Taufik $^{27}$ also concluded that "Indonesia appeared to be pursuing a vigorous outward environmental diplomacy strategy, while little attention was directed inward towards incorporating local conceptions of human-nature relations". In sum, both McLellan and Taufik stated that SBY wanted to build global coalition supporting emission reduction but lack of national and local support in pursuing his vision.

Interestingly President Joko Widodo (Jokowi) showed different approaches. Jokowi only appeared in UNFCCC COP 21 Paris meanwhile Susilo Bambang Yudhoyono (SBY) appeared in two UNFCCC COP in Copenhagen and Bali. Jokowi sent Minister Retno and Minister Siti to represent Indonesia in climate negotiation. Meanwhile SBY is very strongly present in all level negotiation. Jokowi stated that he

${ }^{25}$ Kompas. 2017. Pengusaha anggap aturan Menteri LHK soal Gambut Memberatkan. 5 18. Accessed 6 24 ,

2018.https://ekonomi.kompas.com/read/2017/05/18/ 203010326/pengusaha.anggap.aturan.menteri.lhk.so al.gambut.memberatkan.

${ }^{26}$ McLellan, Sebastian. 2015. Climate Policy under Yudhoyono and Jokowi: Making Progress or Going Backward? November 27. Accessed August 5, 2017. http://www.internationalaffairs.org.au/newsitem/climate-policy-under-yudhoyono-and-jokowimarking-progress-or-going-backward/.

27 Taufik, Op.Cit. 
will support Indonesian diplomacy that benefited Indonesia. However, it is unclear the definition of benefit to Indonesia. REDD+ is also a benefit for Indonesia because developed countries shared their income and technology for forest protection. However, it is unclear on the role of Indonesian government in addressing the interconnection between social injustice and environmental protection.

This research disagree with Rosyidin's argument mentioning Jokowi has less interest in pursuing international due to bigger focus on domestic policy. ${ }^{28}$ This research argued that BRG is part of Jokowi's environmental diplomacy. Environmental diplomacy emphasized internal consolidation that has an impact toward bilateral and multilateral negotiation. This is a bottom-up approach that is radically different with previous regime. This research echoed Qin's opinion that Jokowi wanted to implement results-driven foreign policy. $^{29}$ Multilateralism and great power status are not the only way to achieve significant impact toward Indonesia. Bilateral diplomacy and technical diplomacy can be tools for Jokowi to achieve Indonesian foreign policy.

Indonesia was traditionally used UNFCCC to promote Indonesian national interest in global environmental governance. However, Jokowi regime added Global Peatland Initiatives (GPI) as a new platform for Indonesian environmental diplomacy. The emergence of GPI as a new Indonesian

28 Rosyidin, Mohamad. 2017. "Foreign policy in changing global politics: Indonesia's foreign policy and the quest for major power status in the Asian Century." South East Asia Research 1-17.

${ }^{29}$ Qin, Sophie. 2015. A Retreat From Multilateralism: Foreign Policy Restructuring Under Jokowi. 12 23. Accessed 620118. http://www.internationalaffairs.org.au/australianou tlook/a-retreat-from-multilateralism-foreignpolicy-restructuring-under-jokowi/. platform is not surprising due to the failure of UNFCCC to focus on peatland restoration and conservation. GPI was established in 2015 in Germany as a platform for civil society, states and academia to discuss and draft policies and ideas in peatland restoration. $^{30}$ In 2018, Indonesian Minister for Environment and Forestry Siti Nurbaya Bakar and Deputy for Construction, Operation and Maintenance of Peatland Restoration Agency Alue Dohong attended the second meeting of GPI in Congo.

The emergence of GPI can be analyzed using great power politics. US' decision to neglect of Paris Agreement has a serious impact toward the commitment from developing and developed countries. Northsouth cooperation is a traditional basis of global environmental governance but US' exit marked a new path for a stronger basis of south-south cooperation as shown in GPI. Indonesia's decision to join GPI is a result of Indonesian reformed environmental diplomacy. Instead of dependent on great power aid, Indonesian focused on the development of national resource and built global coalition to support Indonesian goal.

\section{Conclusion and Recommendation}

This research has three conclusions. Firstly, Indonesia is an important actor in the mitigation of many regional and global environmental issues including forest fires and transboundary haze. The success of BRG will have direct implication toward Indonesia emission reduction target. Jokowi has promised to cut Indonesian emission by $29 \%$ in 2030 under business-as-usual and $41 \%$

\footnotetext{
${ }^{30}$ Diamond, Herbert, Willem Ferwerda, Hans Joosten, Tatiana Minaeva, Jack Rieley, Henk Ritzema, and Marcel Silvius. 2004. The Global Peatland Initiative as a partnership. 6. Accessed 6 26, 2018. https://www.researchgate.net/publication/40124541 _The_global_peatland_initiative_as_a_partnership.
} 
Diplomacy Reformed : Case Studies of Greening ASEAN Way and Peat

Restoration Agency

with international support. ${ }^{31}$ To achieve this target, there are two sectors that need Jokowi's attention namely energy sector and land-use reform. Wijaya, et.al., (2017) shows that Indonesia existing policies will not achieve the target and Indonesian government need to strengthen its measures to produce emission less than 2.037 $\mathrm{MtCO} 2.32$

In the context of land-use, land-use change and forestry reform, Wijaya ${ }^{33}$ urged Indonesian government to give priority to peatland restoration. Interestingly, land-use, land-use change and forestry accounted to $48 \%$ Indonesia emission in 2012. It will be bigger after 2015's forest fires. Therefore, Wijaya challenged Indonesian government to extend original mandate of two million hectares peat restoration in 2020 become six million hectares in 2030. This extension will be significantly help Indonesian government to achieve $29 \%$ percent target.

Secondly, the ratification of ASEAN Agreement on Transboundary Haze Pollution and the establishment of peat restoration agency are part of the reinvigoration of Indonesia environmental diplomacy. There is significant difference between SBY and Jokowi's environmental diplomacy especially in peat protection and restoration. $^{34}$ Jokowi's emphasis on peat

31 UNFCCC. 2016. First Nationally Determined Contribution Republic of Indonesia. Bonn: UNFCCC.

32 Wijaya, Arief, Hanny Chrysolite, Mengpin Ge, Clorinda Kurnia Wibowo, Almo Pradana, Andhyta Firselly Utami, and Kemen Austin. 2017. How can Indonesia achieve its climate change mitigation goal? An analysis of potential emissions reductions from Energy and Land-Use Policies. Washington DC: World Resource Institute.

${ }^{33}$ ibid

${ }^{34}$ Santosa, Mas Achmad, and Januar Dwi Putra. 2016. "Enhancement of Forest and Peatland Governance in Indonesia." Indonesian Journal of International Law 344-352. protection must be evaluated regularly in ensuring Indonesia emission reduction target. Land-use and forestry reform are the biggest contributor of Indonesia' emission production. Indonesian peat protection is stronger due to the combination of BRG and KLHK. KLHK is an output of integration of Ministry of Environment and Ministry of Forestry. Meanwhile SBY previously only used BP REDD+ and DNPI that have limited vision on domestic peat protection.

Lastly, Indonesia's reformed environmental diplomacy still faced problem on the relationship between central government and local government. Minister Siti has made promise to assist Congo in its peat protection and Minister Siti must deliver its promise in bringing betterment in Congo. Not only about South-South cooperation, Indonesia also focused to bring peat protection and restoration in Indonesian climate diplomacy with the purpose of ensuring aid and facilities from developed countries. The success of peat protection and restoration can be a tool for Indonesia to shape and formulate global climate negotiation especially during the implementation of Paris Agreement. Peat protection is a global issue and developed countries need to be Indonesia's strategic partner in protecting and restoring global peatland. 
Verdinand Robertua \& Lubendik Sigalingging | Indonesia Environmental

Diplomacy Reformed : Case Studies

of Greening ASEAN Way and Peat

Restoration Agency

\section{REFERENCES}

Acharya, Amitav. 1997. "Ideas, Identity, and Institution Building: From the 'ASEAN Way' to the 'Asia-Pacific' Way." Pacific Review 319-346.

Ali, Saleem, and Helena Vladich. 2016. "Environmental Diplomacy." In The SAGE Handbook of Diplomacy, by Costas Constantinou, Pauline Kerr and Paul Sharp, 601616. London: SAGE.

Alisjahbana, Armida S., and Jonah M. Busch. 2017. "Forestry, Forest Fires, and Climate Change in Indonesia." Bulletin of Indonesian Economic Studies 111-136.

Ardhian, David, Soeryo Adiwibowo, and Ekawati Sri Wahyuni. 2016. "Peran dan Strategi Organisasi Non Pemerintah dalam Arena Politik Lingkungan Hidup." Sodality 210216.

Benedick, Richard E. 1999. "Diplomacy for the Environment." In Environmental Diplomacy, by American Institute for Contemporary German Studies, 3-13. Washington: American Institute for Contemporary German Studies.

Bernstein, Steven. 2001. The Compromise of Liberal Environmentalism. New York: Columbia University Press.

Bull, Hedley. 1977. The Anarchical Society: A Study of Order in World Politics. Basingstoke: Palgrave.

Buzan, Barry. 2004. From International to World Society: English School Theory and the Social Structure of Globalisation. Cambridge: Cambridge University Press.

Chasek, Pamela S. 2001. Earth Negotiations: Analyzing Thirty Years of Environmental Diplomacy. Tokyo: United Nations University Press.

Clapp, Jennifer, and Peter Dauvergne. 2005. Path to a Green World: the Political Economy of Global Environment. Masschusets: MIT Press.

Cochran, Molly. 2009. "Charting the Ethics of the English School: What "Good" is There in a Middle-Ground Ethics?" International Studies Quarterly 203-225.

Deutsche Welle. 2006. Asap dan Perang Kata-Kata. Desember 14. Accessed Desember 2, 2016. http://www.dw.com/id/asap-dan-perang-kata-kata/a-16897824.

Diamond, Herbert, Willem Ferwerda, Hans Joosten, Tatiana Minaeva, Jack Rieley, Henk Ritzema, and Marcel Silvius. 2004. The Global Peatland Initiative as a partnership. 6. Accessed 62018. https://www.researchgate.net/publication/40124541_The_global_peatland_initiative_ as_a_partnership.

Falkner, Robert. 2009. Business Power and Conflict in International Environmental Politics. New York: Palgrave Macmillan.

Falkner, Robert. 2012. "Global environmentalism and the greening of international society." International Affairs 503-522.

French, Hillary. 1999. "How Can We Reconcile the Slow Pace of International Diplomacy with the Growing Urgency of Global Ecological Decline." In Environmental 
Verdinand Robertua \& Lubendik Sigalingging | Indonesia Environmental

Diplomacy Reformed : Case Studies

of Greening ASEAN Way and Peat

Restoration Agency

Diplomacy, by American Institute for Contemporary German Studies, 13-17. Washington: American Institute for Contemporary German Studies.

Jackson, Robert. 2009. "International Relations as a Craft Discipline." In Theorising International Society: English School Methods, by Cornelia Navari, 21-39. New York: Palgrave Macmillan.

Kompas. 2017. Pengusaha anggap aturan Menteri LHK soal Gambut Memberatkan. 518. Accessed

https://ekonomi.kompas.com/read/2017/05/18/203010326/pengusaha.anggap.aturan. menteri.lhk.soal.gambut.memberatkan.

Laferrière, Eric, and Peter Stoett. 1999. International Relations Theory and Ecological Thought: Towards Synthesis. London: Routledge.

Liste, Philip. 2017. "International Relations Norms Research and the Legacies of Critical Legal Theory." 11th Pan-European Conference on International Relations (EISA). Barcelona: European International Studies Association. 1-22.

McLellan, Sebastian. 2015. Climate Policy under Yudhoyono and Jokowi: Making Progress or Going Backward? November 27. Accessed August 5, 2017. http://www.internationalaffairs.org.au/news-item/climate-policy-under-yudhoyonoand-jokowi-marking-progress-or-going-backward/.

Najam, Adil, Mihaela Papa, and Nadaa Taiyab. 2006. Global Environmental Governance: A Reform Agenda. Manitoba: International Institute for Sustainable Development.

Narain, Sunita. 1999. "Environmental Diplomacy in an Unequal World." In Environmental Diplomacy, by American Institute for Contemporary German Studies, 17-25. Washington: American Institute for Contemporary German Studies.

Nguitragool, Paruedee. 2011. "Negotiating the Haze Treaty Rationality and Institutions in the Negotiations for the ASEAN Agreement on Transboundary Haze Pollution (2002)." Asian Survey 51 (2): 356-378.

Pontianak Post. 2016. Revisi Perda Karhutla. 2 25. Accessed 9 12, 2018. https://www.pontianakpost.co.id/revisi-perda-karhutla.

Qin, Sophie. 2015. A Retreat From Multilateralism: Foreign Policy Restructuring Under $\begin{array}{llllll}\text { Jokowi. } & 12 & 23 . & \text { Accessed } & 6 & 26,\end{array}$ http://www.internationalaffairs.org.au/australianoutlook/a-retreat-frommultilateralism-foreign-policy-restructuring-under-jokowi/.

Quayle, Linda. 2013. "National and Regional Obligations, the Metaphor of Two-Level Games, and the ASEAN Socio-Cultural Community." Asian Politics \& Policy 5 (4): 499-521.

Robertua, Verdinand. 2016. "Multi-stakeholder Initiative for Sustainable Development: An English School Perspective ." Jurnal Sospol 154-170.

Rosyidin, Mohamad. 2017. "Foreign policy in changing global politics: Indonesia's foreign policy and the quest for major power status in the Asian Century." South East Asia Research 1-17. 
Verdinand Robertua \& Lubendik Sigalingging | Indonesia Environmental

Diplomacy Reformed : Case Studies of Greening ASEAN Way and Peat

Restoration Agency

Santosa, Mas Achmad, and Januar Dwi Putra. 2016. "Enhancement of Forest and Peatland Governance in Indonesia." Indonesian Journal of International Law 344-352.

Schouenborg, Laust. 2013. The Scandinavian International Society: Primary Institutions and Binding Forces 1815-2010. Oxon: Routledge.

Susskind, Lawrence E. 1994. Environmental Diplomacy: Negotiating More Effective Global Agreements. Oxford: Oxford University Press.

Taufik, Kinanti Kusumawardhani. 2016. "Indonesia's Environmental Diplomacy under Yudhoyono: A Critical-Institutionalist- Constructivist Analysis." The Hague Journal of Diplomacy 1-26.

The Guardian. 2016. Indonesia's forest fires threaten Sumatra's few remaining Orang Rimba. June 7. Accessed August 7, 2017. https://www.theguardian.com/globaldevelopment/2016/jun/07/indonesia-forest-fires-threaten-sumatras-few-remainingorang-rimba.

The Jakarta Globe. 2017. Regulatory Challenges in Peatland Management. September 13. Accessed November 16, 2017. http://insight.jakartaglobe.id/indonesias-regulatorychallenges-people-planet-profit-peatland-management/.

UNFCCC. 2016. First Nationally Determined Contribution Republic of Indonesia. Bonn: UNFCCC.

Wibisono, Christianto. 2015. "Kedaulatan Asap RI." Kompas, October 27: 7.

Wijaya, Arief, Hanny Chrysolite, Mengpin Ge, Clorinda Kurnia Wibowo, Almo Pradana, Andhyta Firselly Utami, and Kemen Austin. 2017. How can Indonesia achieve its climate change mitigation goal? An analysis of potential emissions reductions from Energy and Land-Use Policies, Washington DC; World Resource Institute. 